\title{
LABOR MARKET DUALITY IN JAPAN: A RESILIENCE PERSPECTIVE
}

\section{Introduction}

Among many paths and approaches of different countries towards their goal of gaining economic resilience, Japan has always been an interesting example. Throughout its history, the country has experienced dramatic earthquakes, typhoons, and other natural disasters, which molded the nation and its culture through coexistence with the beautiful yet fiercely unpredictable nature, and taught the people the need of constant readiness for action.

Challenges facing the country varied with the times, but let us take a look at the present-day Japan. Former prime minister Shinzo Abe's term, from the beginning in 2012, was marked by a recovery from the global financial crisis, the Great Tohoku Earthquake, and the Fukushima disaster. On the one hand, this setting was extremely demanding, but on the other hand, created an opportunity for the cabinet to consolidate the nation to rebuild and strengthen the country and the economy. The current PM, Yoshihide Suga (in office since September 2020), has no less challenging job to do as we witness the second year of the COVID-19 pandemic. The spread of the disease led to the introduction of a state of emergency and, eventually, to the historic postponement of the 2020 Tokyo Olympic Games. ${ }^{1}$

All of that happens against a constant need to adapt to modern trends, which slowly but surely keep reshaping the socio-economic landscape: social promotion of women, erosion of the domestic manufacturing and the growth of the service sector, globalization, growing reliance on the Internet, low fertility rate, and the ageing society, while not strictly economic trends, all have significant impact on the ecosystem and put policymaking under pressure. ${ }^{2}$ This includes influence on the regulation of employment in Japan, which is the focus of this paper. The question of how to

ORCID: 0000-0003-2261-6749, DOI: 10.4467/23538724GS.21.007.14839

1 https://www.imf.org/en/Topics/imf-and-covid19/Policy-Responses-to-COVID-19 (accessed: 18.03.2021).

2 T. Kinebuchi, 日本的雇用制度再考「夕テ社会」の力学基礎に [Revisit to the Japanese Style of Employment System: Based on the Dynamics Stemming from the Vertically-Structured Society], “Josai Junior College Bulletin” 2015, vol. 32(1), pp. 1-13. 
survive, adapt and improve - how to achieve economic resilience - remains as important as ever.

This paper reviews recent literature on the Japanese labor market, its current issues and specificity (with duality as one of its primary characteristics). This is done from the labor market resilience viewpoint and chosen variables describing the Japanese labor market are analyzed accordingly. For the purpose of this paper, the conceptualization of labor market resilience is based on Bigos et al. ${ }^{3}$ and further extended by the cultural perspective essential for a better comprehension of the complexity of employment practices existing in Japan.

The presented analysis leads us to think that the duality of the Japanese labor market characterized by resilient regular employment, and highly flexible and vulnerable non-regular workers, is no longer tenable. This, in turn, strongly suggests that the Japanese employment system heads towards a "threshold" or "regime-shift", 4 and its evolution along with new, developing trajectories is calling for greater inclusiveness.

\section{Duality of the Japanese Labor Market}

A dichotomy between protected regular workers and under-protected and underpaid non-regular workers has been deepening in the Japanese labor market especially after the global financial crisis. The phenomenon has been addressed by several researchers. Song $(2014)^{5}$ observes that Japan managed to liberalize employment regulations and working conditions for non-regular workers while maintaining vast protection of regular workers. This was, however, done in favor of investors and exporters and not the Japanese society - workers and households. Moreover, after 2012, earnings growth showed a negative trend, job security diminished and access to social benefits was limited. Subsequently, productivity growth decelerated and employers were not eager to invest in human capital, a critical factor for competitive advantage. ${ }^{6}$

Determinants of labor market duality were examined by Aoyagi and Ganelli through cross-country panel regressions. They found out that increase in women's

3 M. Bigos et al., Review Essay on Labour Market Resilience, INSPIRES, Working paper series 2013, no. 1.

4 B. Walker et. al., Resilience, Adaptability and Transformability in Social-ecological Systems, "Ecology and Society" 2004, vol. 9, issue 2, p. 5, http://www.ecologyandsociety.org/vol9/iss2/art5/ (accessed: 20.04.2021).

5 J. Song, Inequality in the Workplace: Labor Market Reform in Japan and Korea, Cornell University Press 2014, pp. xvi+229.

6 S. Bobowski, B. Drelich-Skulska, After Three Years of Abenomics. Challenges and Recommendations for the Economic Revitalisation Policy in Japan, "Transformations in Business \& Economics" 2016, vol. 15, no. 2A (38A), p. 443. 
labor force participation, shift from manufacturing to services, and economic globalization drive the demand for non-regular jobs. Their results underscore the fact that the duality increases with a higher level of employment protection of regular workers and decreases with higher employment protection of temporary workers. The message is therefore clear, Japan needs labor market reforms that would reduce the difference between regular and non-regular workers' employment regulations. Furthermore, the process should be supported by a change in "soft institutions" (working practices exerted by firms) focused on improving the work-life balance. ${ }^{7}$

However, the direction of regulatory reforms was more into promoting deregulation of non-regular employees and adding to flexibility of market mechanisms than the change in the working practices. ${ }^{8}$ Watanabe argues that "the political resources of and power relations between market-oriented reformers and nonmarket coordination-oriented anti-reformers affected regulatory reform processes and decided their characteristics. ${ }^{9}$ The Liberal Democratic Party (LDP) advanced non-regular employment deregulation by neoliberal "policy entrepreneurs" or "change agents", members of specifically established committees promoting labor market flexibility in reply to business demand. ${ }^{10}$

This provides a good illustration for the varieties of capitalism (VOC) framework, according to which Japan is classified as a coordinated market economy (CME) with "non-market-based coordination". Song claims that growing economic inequalities in Japan derive from path dependency of the labor market and social network reforms biased in favor of big companies and their core legitimate workers. ${ }^{11}$

There is a close relationship between industrial relations, skill formation governance, and production system. Japan relies on a system where company-based unions undertake firm-level bargaining. Japan enjoys a high level of firm-specific skills, which are developed mostly within a firm. Indeed, economic development in Japan was traditionally defined by the close collaboration between the government and private sector marked by "protectionist policies and MITI (Ministry of International Trade and Industry)-centralized governance". ${ }^{12}$ As a result, industrial

7 C. Aoyagi, G. Ganelli, Does revamping Japan's dual labor market matter?, "Economic Systems" 2015, vol. 39, pp. 346, 353.

${ }^{8}$ H.R. Watanabe, Institutional Change Under Neoliberal Pressure: Japanese Regulatory Reforms in Labor and Financial Markets, "Asian Politics \& Policy” 2015, vol. 7, no. 3, pp. 413-432.

9 Ibidem, p. 413.

10 Ibidem.

11 J. Song, Economic Distress, Labor Market Reforms, and Dualism in Japan and Korea, "Governance-An International Journal of Policy Administration and Institutions", July 2012, vol. 25, no. 3, pp. 415-438.

12 K. Kovacic, The Making of National Robot History in Japan: Monozukuri, Enculturation and Cultural Lineage of Robots, The Nissan Institute of Japanese Studies, School of Interdisciplinary Area Studies, University of Oxford, UK, 2018, p. 11. 
manufacturing became an element of creating national identity. This identity is contained in nihonjinron, which literally means "theories on being Japanese" and "refers to the vast array of literature which thinking elites have produced to define the uniqueness of Japanese culture, society, and national character". ${ }^{13}$ The concept puts Japan in a perspective of the "West". "Modern" and "traditional" have always been juxtaposed in Japan e.g. by "hybridized consumer products" sanctioned by their "Japaneseness". ${ }^{14}$ It is hard to question the statement that "rather than being expanded to include new ideas" nibonjinron is "expanded to include new (material) objects". ${ }^{15}$

The duality of the Japanese working life is also a kind of a hybrid consisting of deep-rooted and unique lifetime or formally regular employment, and all other forms of contracting. The accent on cultural values is strong. Japanese-style regular employment is "deeply embedded into complementary practices and institutions, resulting in its resilience and stability". ${ }^{16}$

Labor market duality in Japan, in its specific socio-cultural context, is an inevitable phenomenon to maintain regular (lifetime) employment and keep it resilient, and retain flexibility utilizing non-regular workers. However, under the subsequent shocks, including the newest COVID-19 pandemic, non-regular workers (women, youth, elder, and other) pay the highest price for sustaining this socio-cultural stability.

\section{Methodological Approach to the Labor Market Resilience}

Most scholars develop the resilience theory based on the engineering and the ecological fields of studies. Except these two concepts, the so-called adaptive resilience has developed, which stresses a system capability for continuous adjustments. While the engineering approach sees one state of equilibrium, the ecological one claims that multiple equilibriums exist. In contrast, adaptive resilience concept takes a long-term perspective of a system performance without assuming any states of equilibrium. ${ }^{17}$ Thus, the idea of resilience arose as a crucial aspect of intricate, dynamic systems in a number of disciplines. Resilient (socio-economic) systems can "survive, adapt, and grow regardless of uncertainty and un-foreseen disruptions". ${ }^{18}$

${ }^{13}$ K. Yoshino, Cultural Nationalism in Contemporary Japan: A sociological enquiry, London - New York 1992, p. 2.

${ }^{14}$ K. Kovacic, The Making of National Robot..., p. 11.

15 Ibidem, p. 14.

16 Ch. Moriguchi, H. Ono, Institutional Change in Japan. Japanese Lifetime Employment: A Century's Perspective, Working Paper 2004, Stockholm, p. 3.

17 M. Bigos et al., Review Essay...

18 C. Folke, Resilience: The emergence of a perspective for social-ecological systems analyses, "Global Environmental Change" 2006, vol. 16, p. 16. 
Walker et al. reminds that resilience is about "changing in order not to be changed". ${ }^{19}$ In other words, resilience is the ability to change so as to retain the same identity. ${ }^{20}$

Bigos et al. refer to the VOC theory and point out that in the labor markets, flexibility associated with the competitive model and commitment identified with the cooperative model would improve labor market resilience. ${ }^{21}$ Japan's labor market is an intriguing example as it combines both flexibility and commitment.

Bigos et al. provide a following conceptualization of labor market resilience (see: Figure 1).

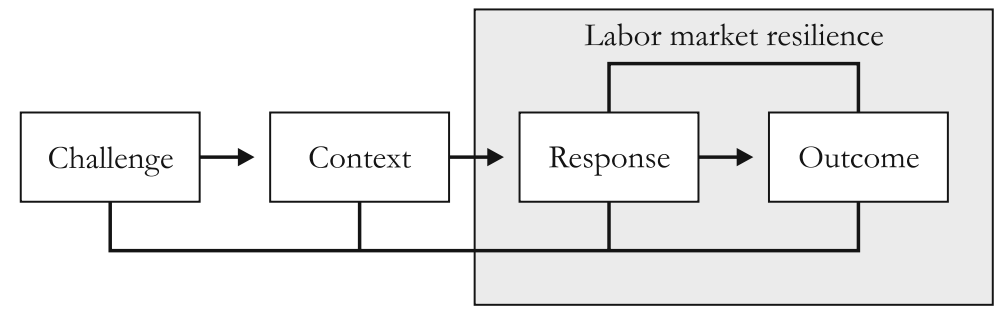

Figure 1. Labor market resilience, conceptual framework

Source: Author's own elaboration based on: Bigos et al., Review Essay on Labour Market Resilience, INSPIRES, Working paper series 2013, no. 1, p. 19.

In the model, the challenge means a kind of disturbance. It could be a recession, a decline in productivity growth, an increase in unemployment, or other disruption, which can be described by indicators such as gross domestic product, unemployment rate, labor force participation rate, etc. The context constitutes an outline of basic labor market structures, which largely depends on the institutional, structural-demographic, and socio-economic conditions. These would imply a closer look into labor contracts, working hours, employment protection, or active labor market policies. Moving forward, the response signifies a feedback mechanism or the ability to handle challenges by "innovating or rearranging their institutional structures" which could be described by policies variable. Finally, the outcome involves bouncing back and recovery by achieving its pre-shock state outcome or even improving it. ${ }^{22}$

19 B.H. Walker, Resilience: what it is and is not, "Ecology and Society" 2020, vol. 25, no. 2, p. 1, https://www.ecologyandsociety.org/vol25/iss2/art11/ (accessed: 15.04.2021).

20 C. Folke et al., Resilience thinking: integrating resilience, adaptability and transformability, "Ecology and Society" 2010, vol. 15, no. 4, p. 20.

21 M. Bigos et al., Review Essay...

22 Ibidem, pp. 19-20. 


\section{Japanese Labor Market Performance Seen as a Challenge}

\section{1) Gross Domestic Product}

Data on Japan's quarterly GDP growth rate leads to the conclusion that the world's third-largest economy has plunged into a recession. This fact strengthens expectations that the cabinet, despite the already redistributed incentive of approx. Three trillion USD, will have to provide the economy with another stimulus package. ${ }^{23}$ Since December 2012 recession defined as two consecutive negative quarter-on-quarter changes in constant prices occurred once, at the turn of the years 2019 and 2020. The first quarter of 2021, however, also showed negative figures.

In October 2019 the government increased the consumption tax from 8\% to $10 \%$, which is believed to hurt domestic demand. The rise was the second tranche of the consumption tax hike planned by Abe's cabinet. The first one took place in April 2014, also marked by a negative GDP growth rate. In 2020, the so-called "corona shock" or COVID-19 pandemic aggravated the situation. Current contractions are predicted to exceed that of 2009, the aftermath of the global financial crisis. ${ }^{24}$

2) Unemployment rate and labor force participation

In 2019, the unemployment rate in Japan reached a record-low value of 2.3\% (as a $\%$ of the total labor force). The unemployment rate among women fell to $2.2 \%$, while among men to $2.4 \%$. According to OECD, youth unemployment rate stood at $5.1 \%$ for men and at $4 \%$ for women in $2020 .{ }^{25}$ The share of the youth not in education, employment, or training (NEET) in total (as a \% of the youth population), decreased from $4.2 \%$ in 2012 to $3.1 \%$ in 2019 (male $2.8 \%$ in 2012 and $2.7 \%$ in 2019; female $5.6 \%$ and $3.7 \%$ respectively). ${ }^{26}$

Nonetheless, Japan is characterized by a relatively high long-term unemployment rate of $28 \%$ (2020). In comparison, at the same time, the Republic of South Korea recorded the lowest long-term unemployment rate of $0.6 \%$ among the OECD countries, the US 5.67\%, while the OECD average stood at $18.4 \%{ }^{27}$

23 L. Kihara, Japan eyes another big stimulus package before possible Sept poll - Nikkeei, Reuters, 10 June 2021, https://www.reuters.com/world/asia-pacific/japans-suga-compile-big-stimulus-packagearound-summer-nikkei-2021-06-09/ (accessed: 8.07.2021).

${ }^{24}$ M. Hirano, Japan's GDP likely plunged 26\% in April-June quarter, Nikkei Asia, 1 August 2020, https://asia.nikkei.com/Economy/Japan-s-GDP-likely-plunged-26-in-April-June-quarter (accessed: 5.07.2021).

25 OECD, Youth unemployment rate, https://data.oecd.org/unemp/youth-unemploymentrate.htm (accessed: 5.07.2021).

26 World Bank Share of youth not in education, employment or training, total (\% of youth population) - Japan, https://data.worldbank.org/indicator/SL.UEM.NEET.ZS?locations=JP (accessed: 5.07.2021).

27 OECD, Long-term unemployment rate, https://data.oecd.org/unemp/long-term-unemployment-rate.htm (accessed: 5.07.2021). 
Total labor force participation rate (as a \% of total population ages 15-64) increased by 5 pp to $79.2 \%$ in 2019 (in the EU the rate reached $73.3 \%$, in the US $72.6 \%$, and Korea $69.4 \%$ ) leaving $20.8 \%$ of the population at working age outside the labor force. Female LFPR was at $71.7 \%$ in 2019 (63.6\% in 2012) with only $28.3 \%$ of women being inactive, while male LFPR stood at $86.4 \%$ in 2019 (84.5\% in 2012). ${ }^{28}$

\section{3) Employment}

The employment to population ratio was at $69.3 \%$ for men $(2 \mathrm{pp}$ increase compared to 2012 ) and $51.4 \%$ for women in 2019 (unprecedented 5 pp growth compared to 2012) ${ }^{29}$ Altogether, for people aged 15 and older, the rate was $60.5 \%$ in $2020(56.7 \%$ in 2012)..$^{30}$

After 2012 part-time employment reached a peak in $2014-33 \%$ of total employment - and decreased to $31.5 \%$ in 2017 . At the same time, the OECD average was at $25 \%$. Part-time employment accounted for $48 \%$ of total female employment and $18.6 \%$ of total male employment. ${ }^{31}$ Between 2012 and 2019 the share of parttime employment grew in particular for females and males from the 15-24 years old age group, $11 \mathrm{pp}$ and $8 \mathrm{pp}$ respectively. ${ }^{32}$

It needs to be stressed that in Japan regular employment is restricted to a very specific form of hiring. A regular worker is one whose employment contract fulfills the three conditions. These are open-ended agreement, full-time dimension and direct employment. If any of these conditions are modified, the employment is not considered a regular one. So regular workers constitute a distinctive and privileged social group in the Japanese society. Non-regular employment type combinations can be as follows: 1) part-time workers: both fixed-term and open-ended, part-time, direct employment; 2) temporary workers: relatively short fixed-term, full-time, direct employment; 3) dispatched workers from temporary agencies: both fixed-term and open-ended, full- or part-time, indirect employment; 4) contract employees: relatively long fixed-term, fulltime, direct employment; 5) entrusted employees: relatively long fixed-term, full-time, direct employment (senior-aged worker, re-hired etc.); 6) other: none of the above. ${ }^{33}$

28 World Bank, Labor force participation rate, https://data.worldbank.org/indicator/SL.TLF. ACTI.ZS?locations=JP (accessed: 5.07.2021).

29 OECD.Stats, Employment/population ratio, https://stats.oecd.org/index.aspx?queryid $=54742$ (accessed: 9.07.2021).

30 World Bank, Employment to population ratio, https://data.worldbank.org/indicator/SL.EMP. TOTL.SP.ZS?locations=JP (accessed: 9.07.2021).

31 World Bank, Part time employment, https://data.worldbank.org/indicator/SL.TLF.PART. ZS?locations=JP (accessed: 9.07.2021).

32 OECD.Stats, Employment: Share of employed in part-time employment, https://stats.oecd. org/index.aspx?queryid $=54746$ (accessed: 9.07.2021).

33 Y. Asano, Overview of Non-regular Employment in Japan, The Japan Institute for Labour Policy and Training, JILPT Reports 2010, no. 10, p. 2, https://www.jil.go.jp/english/reports/documents/jilpt-reports/no.10_japan.pdf (accessed: 10.05.2021). 
This sharp distinction divides the working society into the favored ones and others. The second group has relatively little to no safety net and used to be underpaid. This duality in the society is well illustrated by the concept of "outsiders" (soto) and "insiders" (uchi) accordingly non-regular and regular employees. Moreover, the transition from non-regular to regular employment is difficult.

\section{Basic Labor Market Structures in Japan}

1) Working hours

According to OECD, between 2012 and 2019, Japan reduced its average annual hours actually worked per worker by $6 \%$. At the same time, the OECD average declined by $1 \%$ and reached 1779 hours worked, 82 hours worked more than in Japan. ${ }^{34}$ It might be said that, at least formally, the image of Japan as a country that is notoriously overworked is a thing of the past. However, the OECD survey covers all workers and does not ask for employment status. The data includes regular and non-regular workers and in Japan the share of non-regular workers is high.

\section{2) Employment security}

The area of employment conditions in Japan is heavily regulated, and there are strict provisions on what position can be filled with, e.g., dispatched workers. In the case of regular workers, dismissals are very difficult to perform. Termination is possible only if an employer "has objectively reasonable grounds" so the practice of "severance packages" "in exchange for the employee's voluntary resignation and waiver of claims against the employer" has emerged. ${ }^{35}$ Nevertheless, there are plenty of unwritten standards, previous court decisions, and cultural norms that strongly influence the interpretation of the laws, which may put an employer in a difficult situation. ${ }^{36}$ The increasing number of non-regular employees is one of the reasons why the trade union density has decreased in Japan. In 2017 trade union density in terms of active employees reached $17.1 \%$, compared to $17.7 \%$ in $2013 .{ }^{37}$

\section{3) Active labor market policies}

Finally, active labor market policies (ALMPs) include job search assistance, vocational guidance or counseling, and wage subsidies. Many effective activation measures can strengthen the resilience of a labor market. Interestingly, in 2018 public

\footnotetext{
34 OECD, Hours worked, https://data.oecd.org/emp/hours-worked.htm (accessed: 12.07.2021).

35 L. Carter, K. Nasuda, An overview of Japanese employment law, "DLA Piper, BRIEFING", January-February 2014, vol. 21, no. 1, p. 14.

36 Ibidem.

37 E. Packalen, Working life in Japan, Eurofound, 6 March 2019, https://www.eurofound.europa. eu/country/japan\#actors-and-institutions (accessed: 10.05.2021).
} 
expenditure as a percentage of GDP on training in Japan was at $0.01 \%$, $4^{\text {th }}$ from the bottom among the surveyed countries. Expenditures on employment incentives reached $0.06 \%$ ( $0.09 \%$ for the OECD average) in 2018, down by 0.02 pp compared to 2012. Furthermore, out-of-work income maintenance and support accounted for $0.16 \%$ of GDP in 2018 ( $0.6 \%$ for the OECD average)..$^{38}$

There is a "chasm in benefit coverage" in Japan, which occurs due to the limited access to unemployment benefits. ${ }^{39}$ This proves that employment in Japan has always been of outstanding importance. The obligation to work was imposed on the Japanese by Japan's Constitution, which also assured the people the right to fulfill this requirement. Such a provision left the government room for intervention in the labor market. ${ }^{40}$

\section{Socio-cultural context for labor market functioning in Japan}

1) Overview of the Japanese model of employment

The common practice in Japan is that companies hire new graduates in April every year, all at once, and train them in-house according to a company's technologyspecific requirements. The training is done over a long period and is intended to enhance labor productivity, international competitiveness and minimize unemployment. This typical work style has been recognized both in the country and abroad "for its outstanding economic rationality". ${ }^{41}$

However, nowadays intensifying competition due to the internationalization of Japanese companies and structural changes, such as aging society or technological advancement, contributed to serious labor shortages in the country and added to a discussion on the future of the traditional employment system.

Traditional work style in Japan can be described by three characteristics, the socalled "three sacred treasures" sanshu no shinki of the Japanese management. The first one is permanent or lifetime employment (shushinkoyo), the second one is seniority criterion (nenkosel), while enterprise union (kigyobetsu kumial) constitutes the

\footnotetext{
38 OECD.Stat, Public expenditure and participant stock on LMP, https://stats.oecd.org/Index. aspx?DataSetCode=LMPEXP (accessed: 12.07.2021).

39 J.P. Martin, Activation and Active Labour Market Policies in OECD Countries: Stylized Facts and Evidence on their Effectiveness, "IZA Policy Papers" 2014, no. 84, https://izajolp.springeropen.com/ articles/10.1186/s40173-015-0032-y (accessed: 14.07.2021).

40 U. Schaede, What happened to the Japanese Model? "Review of International Economics" 2004, vol. 12, no. 2, p. 283.

41 I. Yamamoto, The Need for Work Style Reform in Japan \& Its Impact, Special Article 1, "Japan SPOTLIGHT", May-June 2017, p. 49, https://www.rieti.go.jp/en/papers/contribution/yamamoto/data/04.pdf (accessed: 12.07.2021).
} 
third treasure. ${ }^{42}$ These practices have shaped recruiting routine as well as the whole lifestyle in the society.

Lifetime employment is not a guarantee but seniority-based career progression and in-house training aimed at acquisition of firm-specific skills give a worker vision of stability and permanent employment. ${ }^{43}$ Japanese companies developed a system of teamwork with indefinite duties by training "generalists" who can take on a wide range of duties in response to the increase in various labor demands. ${ }^{44}$ As a result, an employee is equipped with firm-specific skills that "have no option value outside of the firm". 45

Regular employee (seishain) in Japan is associated with long hours worked during the week, poor work-life balance, long hours of commuting, relocations, etc. On the other hand, there is a strong safety net included, bonuses, and it is almost impossible to dismiss such a worker. Becoming a regular employee after graduation is associated with achieving life success. Non-regular workers (hiseishain) are the employees who tend to work shorter hours under fixed-term contracts without career perspectives. ${ }^{46}$ Such employees are perceived as people from "outside", so their loyalty and sense of responsibility towards the company are considered to be lower than that of regular workers.

2) Socio-cultural background behind the working style in Japan

"Soft institutions" or working practices applied by the Japanese companies are deeply rooted in the national cultural values and have been practiced for a long time. Hite and Hawes (1991) indicate that presupposed cultural values within a group evolve over time, and serve to separate its own culture from others. ${ }^{47}$ "The use of 'our tradition', which is supposed to be long known to the group, effectively serves to maintain and enhance the secure, time-oriented sense of the identity of the ethnic group". 48

42 J.C. Abegglen, The Japanese factory: aspects of its social organization; the Center for International Studies, Massachusetts Institute of Technology (MIT) 1958.

43 S. Jacoby, The Origins of Internal Labor Markets in Japan, "Industrial Relations: A Journal of Economy and Society” 1979, vol. 18, issue 2, p. 188.

44 T. Kinebuchi, 日本的雇用制度再考「夕テ社会」の力学在基礎に [Revisit to the Japanese Style...]

${ }^{45}$ H. Ono, Japanese Labor Market Reform. Why is It So Difficult?, Working Paper April 2002, no. 146, Stockholm School of Economics, p. 3.

46 Y. Arai, H. Ichimura, D. Kawaguchi, The educational upgrading of Japanese youth, 1982-2007: Are all Japanese youth ready for structural reforms?, "Journal of The Japanese and International Economies" 2015, vol. 37, p. 111.

47 R.E. Hite, J.M. Hawes, Understanding The Japanese Culture For Business Success, "Journal of Managerial Issues" 1991, vol. 3, no. 1, pp. 31-45.

48 K. Yoshino, Cultural Nationalism..., p. 60. 
Brown (1966) and Yoshino (1992) put forward a notion of a village - mura, ${ }^{49}$ and more precisely of primary village (dai ichi mura) and secondary village (dai ni mura) ${ }^{50}$, as the model of the contemporary firm organization. The primary village refers to "the socio-cultural principles of the way of life in the village of the Tokugawa" period Japan ${ }^{51}$ (p. 56). That time, life in a community relied on an orderly system of (economic) cooperation. Nibonjinron considers practices observed in the company and other aspects of Japan's modern social life peculiarly Japanese, and relates these characteristics to "peasants solidarity and patterns of behavior in the pre-industrial village community". ${ }^{52}$ Academic literature pinpoints the continuity between kyodotai, the pre-industrial village community, and the relations in the modern business institution. ${ }^{53}$

Brown recalls the following socio-cultural principles, specified by professor Kamishima Jiro, that organized life in the primary village: 1) "mental autarky" meaning self-efficiency achieved through teamwork; 2) shintoism, embodied in practices and events, e.g., seasonal festivals (matsur), aimed at unifying the group emotionally; 3) "gerontology" or respect for elders as they are wiser thanks to their memory and experience; 4) familism, explaining the roles people play and enhancing the way they communicate; 5) feudalism, family standing in the village hierarchy. ${ }^{54}$

High-speed industrialization and bureaucratization taking place during Meiji Restoration lacked manpower eventually absorbed from rural areas. Rapid changes left no time for developing a new model of social behavior so the needed social patterns were transferred with the villagers. As a consequence, the term "secondary village" was coined to explain the principles functioning in the contemporary Japanese firm: 1) "mental autarky" interpreted as a division of a company and lack of communication between departments; 2) shintoism, which is expressed in different ways of socialization aimed at strengthening association with the company, its kyodotai (sports events, company picnics like hanami, trips, after-work meetings are just some examples of these practices); 3) "gerontology" seen as the cultural origin of the system valuing lengthy service; 4) familism and feudalism, symbolized by the size of the company rather than a family. The progressing process of urbanization and industrialization created a vacuum where an individual's identity or status should be, and the company successfully filled this gap..$^{55}$

\footnotetext{
49 Ibidem, p. 69.

50 W. Brown, Japanese Management. The Cultural Background, "Monumenta Nipponica" 1966, vol. 21 , no. $1 / 2$, pp. $56-57$.

51 Ibidem, p. 56.

52 K. Yoshino, Cultural Nationalism..., p. 60.

53 Ibidem, p. 122.

54 W. Brown, Japanese Management...

55 Ibidem, pp. 57-58.
} 
Japan's institutions of lifetime employment and pay based on age are considered as essential features of familism developed after the second world war among male regular workers employed in large companies. Familism has often been used "to explain the uniqueness of Japan's employment practices". ${ }^{56}$ The perspective of being employed by one company through one's whole life offers "a sense of security". The system in which workers devote their careers to one employer and coexist with one another "for the rest of their working lives" provides a foundation for maintaining "the spirit of the cooperative body" (kyodotai teki seishin) in the firm. ${ }^{57}$

Brown compares the "pre-Meiji village kyodotal" to the large modern company as both constituted and constitute a "fundamental economic unit" ${ }^{58}$ Kyodotai dates back to Yayoi wet paddle rice cultivation when the construction of a large-scale watering system required close teamwork among villagers. "Basic Japanese ethical attitudes" had been settled in such a primordial organization life and other social institutions, which developed all over the nation's history, "were characterized by these same ethical patterns". ${ }^{59}$

Moreover, familism serving as a tool of communication is well pronounced in an informal institution of parent-child (oyabun-kobun) system. The system provides the ground for stabilizing relationships with newcomers and guarantees persistence the past traditions. The gyabun-kobun mechanisms were also a kind of family protection system, broken by war, urbanization, overpopulation, and omnipresent scarcity. ${ }^{60}$

These principles lead Japanese behavior outside of the family, and produce a sense of reliability and commitment in the society. ${ }^{61}$ Yoshino stresses that lifetime employment allowed for sustained cultural entity as it marked historical continuity of what is "ours" and belongs to "our realm", by contrast to cultural elements borrowed from other nations. This consciousness of what is exclusively ours is a constitutive factor for the common sense of uniqueness and has an effect on the absorption of foreign cultures. ${ }^{62}$

\section{Responses to Working Style Challenges}

Between 2012 and 2020 Japan was led by Shinzo Abe, the longest-serving Prime Minister in the country's post-war history. PM Abe's economic policy gained

56 K. Yoshino, Cultural Nationalism..., p. 68.

57 W. Brown, Japanese Management..., p. 49.

58 Ibidem, p. 56.

59 Ibidem.

${ }^{60}$ I. Ishino, The Oyabun-Kobun: A Japanese Ritual Kinship Institution, "American Anthropologist" 1953, vol. 55, issue 5, pp. 704-705.

61 R.E. Hite, J.M. Hawes, Understanding The Japanese Culture...

${ }^{62}$ K. Yoshino, Cultural Nationalism..., p. 90. 
popularity as Abenomics, and involved aggressive monetary policy, flexible fiscal policy, and growth strategy. These three pillars constituted the so-called three "arrows" of Abenomics. ${ }^{63}$

The basis for the third arrow was Japan's Revitalization Strategy, announced on 14 June 2013. In this document, Abe's cabinet stressed the significance of productivity increase ("productivity revolution") and the advancement of the quality of workforce in view of the future challenges. Focus was placed on human resources in general, but the potential of an individual was also accentuated. In the strategy there were three action plans mentioned: 1) industry revitalization plan; 2) strategic market creation plan; 3) strategy of global outreach, out of which the first one targeted the improvement of labor, in particular. ${ }^{64}$ The industry revitalization plan announced that the government would i.a. reorganize the employment system and enhance the private sector to take initiative in strengthening human resources. A whole chapter in this action plan was devoted to reforming the employment system and reinforcing human resources capabilities. ${ }^{65}$

The most important implementation of the above-mentioned declarations was a long-awaited labor market reform aimed at modernizing its labor laws - "Work Style Reform" enacted in 2018. The reform was a part of PM Shinzo Abe's structural reforms package and it targeted widely discussed issue related to the future of employment: the duality of the Japanese labor market ${ }^{66}$. It also meant to enhance the promotion of the employment of women and elder people, as it took the effort to modernize employment practices. The reform was based on three pillars: ${ }^{67}$

1) improvement in lengthy working hours including the introduction of a regulatory limit on overtime work (a cap of 100 hours a month on overtime, unprecedented since the Labor Standards Act took effect in 1947). It came into effect in April 2019 for large companies and a year later for small- and medium-sized companies,

63 A.M. Dzienis, The Potential Impacts of Brexit on the Japanese Economy [in:] Brexit and the Consequences for International Competitiveness, ed. A.M. Kowalski, New York 2018, pp. 271-290.

64 Japan Revitalization Strategy - Japan is Back, Prime Minister of Japan and His Cabinet, 14 June 2013, https://www.kantei.go.jp/jp/singi/keizaisaisei/pdf/en_saikou_jpn_hon.pdf (accessed: 12.07.2021).

65 Industry Revitalization Plan, Prime Minister of Japan and His Cabinet, http://www.kantei.go. jp/jp/singi/keizaisaisei/pdf/en_sesakurei.pdf (accessed: 12.07.2021).

${ }_{66}$ M.C. Urban, S. Johal, Understanding the Future of Skills, Trends and Global Policy Responses, Skills Next 2020, https://fsc-ccf.ca/wp-content/uploads/2020/01/UnderstandingTheFutureOfSkills-PPF-JAN2020-EN.pdf (accessed: 12.07.2021).

${ }^{67}$ A. Okutsu, E. Sugiura, Five things to know about Japan's work reform law, Nikkei Asia, 29 June 2018, https://asia.nikkei.com/Economy/Five-things-to-know-about-Japan-s-work-reform-law (accessed: 12.07.2021). 
2) improvement in the working conditions of non-regular workers by means of equal pay for equal work,

3) a system of exemption for white-collar workers from overtime limits. It applies to those with annual incomes of more than 10.75 million JPY (97,500 USD) and will include product developers, financial traders, bankers, consultants, and researchers, among others. The exemption is thought to enable them to choose flexible working hours.

Apart from changes imposed by the government, companies themselves modify recruitment routine trying to adapt to the changing reality. Keidanren (Japan Business Federation) called for universal introduction of "job-type" (jobu gata) employment system as early as in spring 2021. The system is thought to efficiently match human resources with jobs and increase competitiveness of companies. Jobtype employment denies seniority wages (nenko chingin) and age-based promotion (junokuri jinji $)^{68}$ and helps pushing forward structural changes towards results-oriented employment system. ${ }^{69}$ The new scheme clearly defines duties within a job, establishes wages based on achievements/duties and individual wage rises along with changes in job content, opens recruitment and makes termination of employment contracts easier in case of, e.g., insufficient skills. ${ }^{70}$ The idea is to create autonomous career development of individual employees especially in companies that deal with technological innovation, in manufacturing and non-manufacturing sectors. Jobtype employment aims at mid-career professionals as serious labor shortages in fast growing industries loom.

At the same time, Japanese companies have been undergoing the process of robotization and automation. Increasing reliance on technology has provided favorable environment for gig work expansion. Indeed, Abe's government officially popularized gig work. Through this new form of work authorities tried to address the growing needs for flexible employment, choice and freedom. ${ }^{71}$

68 Y. Mizuno, ジョブ型を甘くみるな.人事 ·組織、根本から見直しを [Do not underestimate jobu-gata. Towards radical revision of personnel and organization], Nihon Keizai Shimbun (Nikkei), 20 January 2021, https://www.nikkei.com/article/DGXZQODK184VY0Y1A110C20 00000/ (accessed: 24.04.2021).

69 Nihon Keizai Shimbun (Nikkei), 年功・順送り人事では変化に後れを取る [The system falls behind the change because of seniority based wages and postponed promotion], 16 June 2020, https://www.nikkei.com/article/DGKKZO60365470V10C20A6EA1000/ (accessed: 24.04.2021).

70 Mizuno Y., ジョブ型を甘くみるな.人事・組織、根本から見直しを [Do not underestimate jobu-gata...]

71 S. Shibata, Gig Work and the Discourse of Autonomy: Fictitious Freedom in Japan's Digital Economy, “New Political Economy” 2020, vol. 25, issue 4, pp. 535-551. 


\section{Identified Outcomes and Discussion}

The Japanese institution of lifetime employment proved persistent. North described institutions as "the rules of the game in a society". ${ }^{72}$ These rules evolved as a result of a dynamic interplay between management, labor, and government in the face of changing surroundings. Subsequently, present long-term employment practices in Japan are genuinely embedded into the socio-economic system, leading to its resilience and strength. However, under the uncertain environment, apart from voluntary retirement another labor adjustment mechanism has developed: non-regular employment. ${ }^{73}$ The "company men" $" 74$ could survive thanks to the more flexible manpower represented especially by women, young and elder people being "the buffer capacity that allows persistence". ${ }^{75} \mathrm{~A}$ regular employee continues to be what Yoshino describes as the typical agent of the uniqueness of Japanese social culture ${ }^{76}$, although it becomes clear that the system does not correspond with the changing surroundings.

The growing number of non-regular workers was hit hard by the COVID-19 pandemic crisis and resulted in a widening gender gap as, in total, women have suffered more than men. ${ }^{77}$ Nikkei Review points to "expectations of sacrifice and employee hierarchy" 78 and recalls that even before the pandemic Japan scored low by international standards in terms of the gender gap. Japan was ranked 121 out of 153 surveyed countries in the World Economic Forum's 2020 Global Gender Gap Report ${ }^{79}$. The so-called "womenomics" policy introduced by Shinzo Abe in 2012, driven mostly by the economic reason of declining labor availability, contributed to the increase in female employment. Nevertheless, the majority was employed part-time. $^{80}$

In Japan, the disparities between the status of regular and non-regular workers result in a gender gap and strengthen the exclusiveness of certain groups in economic and social structures. By contrast, "decent work", as perceived by one of the 17 United Nations' Sustainable Development Goals, is not only about the

\footnotetext{
72 D.C. North, Institutions, Institutional Change and Economic Performance, Cambridge 1990, p. 3.

73 Ch. Moriguchi, H. Ono, Institutional Change in Japan ..., p. 12.

74 K. Yoshino, Cultural Nationalism...

75 C. Folke, Resilience: The emergence..., p. 259.

${ }^{76}$ K. Yoshino, Cultural Nationalism..., p. 135.

77 R. Imahashi, Pandemic widens gender gap across Asia. India and Indonesia tumble in WEF ranking; Japan and South Korea inch up, Nikkei Asia, 31 March 2021, https://asia.nikkei.com/Spotlight/ Society/Pandemic-widens-gender-gap-across-Asia (accessed: 12.07.2021).

78 Ibidem.

79 Global Gender Gap Report 2021, Insight Report, March 2021, http://www3.weforum.org/ docs/WEF_GGGR_2021.pdf (accessed 12.07.2021).

80 R. Imahashi, Pandemic widens...
} 
economic aspects of work but also appeals to cultural perception of "inequality, inclusion and a commitment to leave no one behind". ${ }^{81}$ The UN agenda makes this issue a common goal, and "offers prospects for personal development". ${ }^{82}$

Soini and Dessein thoroughly discussed the culture factor in the sustainability perspective and stressed that obtaining sustainability goals relies upon culturally embedded actions and behavior. They describe three "representations" of culture in sustainability, all three potentially helpful in finding a suitable approach to it. The first is "culture in sustainability", the second "culture for sustainability", and the third "culture as sustainability". ${ }^{83}$ The last two concepts are more functional and dynamic in their perception of culture and fit well in the discussion. Culture for sustainability considers culture to be essential reserve for economic development and means that "cultural values and perceptions" have to be accounted for when addressing sustainability. The idea of culture as sustainability sees culture as an essential infrastructure for achieving sustainability goals, which implies that "sustainability becomes embedded in culture". ${ }^{84}$ In other words, "culture is the foundation for transformation towards sustainability" ${ }^{85}$ while resilience can be seen as a critical instrument for sustainable development. ${ }^{86}$

However, Japanese cultural values and perceptions present in the nation's unique employment practices act, to some extent, against sustainability. Despite their potential to operate as agents for change, the pressure from outside demonstrates their exclusiveness rather than the ability to transform following the challenges like gender equality or technological advancement.

Thus, in the analysis of resilience along with the conceptualization outlined in the section 3, the cultural component is of particular importance. Its complementary role in the context examination gives better understanding of empirical findings and lays grounds for more efficient governance.

Prioritizing regular workers' resilience over non-regular ones aggravates inequalities, and hence affects future generations. How to retain the cultural identity without sacrificing others is a pressing issue. That is why resilience thinking may offer valuable directions. It is no more about incremental growth, efficiency, or optimization,

81 ILO, Decent work and the 2030 Agenda for sustainable development, https://www.ilo.org/global/ topics/sdg-2030/lang--en/index.htm (accessed: 24.04.2021).

82 European Commission, Employment and decent work, https://ec.europa.eu/international-partnerships/topics/employment-and-decent-work_en (accessed: 5.07.2021).

83 K. Soini, J. Dessein, Culture-Sustainability Relation: Towards a Conceptual Framework, "Sustainability" 2016, vol. 8(167), pp. 3-4.

84 Ibidem, p. 3.

85 Ibidem, p. 4.

86 U. Pisano, Resilience and Sustainable Development: Theory of resilience, systems thinking and adaptive governance, ESDN Quarterly Report 2012, no. 26. 
"it is about understanding and engaging with a changing world". ${ }^{87}$ Walker and Salt claim that optimization of specific components of an intricate system of humans reduces the system's resilience. ${ }^{88}$ Resilience thinking draws attention to systems thinking with fundamental objective of understanding the hidden and entrenched causes of problems. Therefore, it is necessary to analyze and interpret particular variables that characterize the system in which these issues are nested. ${ }^{89}$

Finally, in the resilience theory, transformability is the capability to design a fresh system when the so-far structures become untenable. ${ }^{90}$ Folke et al. argue that transformability implies finding new stability by including new "components and ways of making a living". ${ }^{91}$ Last but not least, it is worth mentioning the concept of threshold in the resilience discourse. It is defined as "the point where a system flips from one equilibrium state to another". ${ }^{92}$ It appears that the Japanese employment system heads towards a threshold. It stands at a point when the government and business implement measures trying to reorganize it along new trajectories, hopefully not only superficially.

\section{Conclusions}

Japanese unique employment practices manifested in lifetime employment have started to wane in the 90s, when it became clear that Japanese organizational management is compatible with Japanese society, but it does not correspond with globally applied schemes ${ }^{93}$. Additionally, after the global financial crisis, non-regular employment has been growing, leading to deepening socio-economic discrepancies between this group and regular workers. This phenomenon, fueled by the economic slowdown, sluggish productivity, and loss of competitiveness of Japanese companies, has grown into a significant challenge for Japan.

Yet, the analysis of indicators describing Japan's labor market performance reveals its tightness and limited openness to workers' mobility. The high economic

\footnotetext{
87 B. Walker, D. Salt, W. Reid, Resilience Thinking. Sustaining Ecosystems and People in Changing World, Washington - Covelo - London 2006, p. 14.

88 Ibidem, p. 9.

89 U. Pisano, Resilience and Sustainable Development...

90 B. Walker, D. Salt, W. Reid, Resilience Thinking...

91 C. Folke et al., Social-ecological resilience and biosphere-based sustainability science, "Ecology and Society" 2016, vol. 21, issue 3, p. 41, http://www.ecologyandsociety.org/vol21/iss3/art41/ (accessed: 20.04.2021).

92 F. Berkes, C. Folke, Linking Social and Ecological Systems for Resilience and Sustainability, Beijer Discussion Paper Series 1994, no. 52, p. 4.

93 T. Kinebuchi, 日本的雇用制度再考「夕テ社会」の力学考基礎に [Revisit to the Japanese Style...]
} 
activity of the population was mostly triggered by the expansion of other than regular forms of employment, fitting for those who are not able to follow the traditional full-time, long-term service. By utilizing non-regular workers, companies could adjust to the changing environment, and save regular (core) workers. This contributed to the resilience of the institution of lifetime employment. Non-regular workers, however, have been underestimated and underpaid. Labor market duality has been not only about employment conditions, but also has exposed culturally explainable but no longer acceptable social disparities resulting in, e.g., the gender gap.

These issues were partially addressed by Abenomics, which acknowledged the importance of structural reforms but finally left them halfway through. "Work Style Reform" enacted in 2018 aimed at reforming the employment system, reinforcing human resources capabilities, and increasing productivity, but also gave room for several exemptions, which left the nation in doubt. Finally, we have witnessed the gradual introduction of new job-type employment. The novel system initiated by business seems to polarize regular employment while the expansion of gig work would rather add to non-regular employment leaving more options for women, youth, elders, and others.

A careful resilience analysis of a labor market provides a better understanding of the socio-economic context, and cultural background for social behavior, essential for addressing the challenges efficiently. The shock initiated by the COVID-19 pandemic has become a window of opportunity for real change. Guidance may be thinking the whole system, and the SDG 8 - decent work. Building inclusive diversity is crucial for general resilience. On this path, cultural mindset to achieve change for the whole society and future generations may be generated by a close collaboration of agents that empower various social groups.

The job-type employment idea and the public discussion on the future of employment institution in Japan may be the threshold, opening the system to a long-awaited chance for transformation. Bearing in mind how long the current system has been in place and how deeply its roots overgrow the Japanese society, this conclusion is by no means trivial. As such, it requires further careful observation and in-depth analysis, constituting a very interesting prospect for future research. New employment practices would require a refreshed management scheme, focusing not only on individual achievements but also on organizational culture in individuals-centered environment, new areas for implementing uniquely Japanese approaches.

\section{References}

Abegglen J.C., The Japanese factory: aspects of its social organization, the Center for International Studies, Massachusetts Institute of Technology (MIT) 1958.

Aoyagi C., Ganelli, G., Does revamping Japan's dual labor market matter?, "Economic Systems" 2015, vol. 39 . 
Arai Y., Ichimura H., Kawaguchi D., The educational upgrading of Japanese youth, 1982-2007: Are all Japanese youth ready for structural reforms?, "Journal of The Japanese and International Economies" 2015, vol. 37.

Asano Y., Overview of Non-regular Employment in Japan, The Japan Institute for Labour Policy and Training, JILPT Reports 2010, no. 10.

Berkes F., Folke C., Linking Social and Ecological Systems for Resilience and Sustainability, Beijer Discussion Paper Series 1994, no. 52.

Bigos M., Qaran W., Fenger M., Koster F., Mascini P., van der Veen R., Review Essay on Labour Market Resilience, INSPIRES, Working paper series 2013, no. 1.

Bobowski S., Drelich-Skulska B., After Three Years of Abenomics. Challenges and Recommendations for the Economic Revitalisation Policy in Japan, "Transformations in Business \& Economics" 2016, vol. 15, no. 2A (38A).

Brown W., Japanese Management. The Cultural Background, "Monumenta Nipponica" 1966, vol. 21, no. $1 / 2$.

Carter L., Nasuda K., An overview of Japanese employment law, "DLA Piper, BRIEFING", JanuaryFebruary 2014, vol. 21, no. 1.

Dzienis A.M., The Potential Impacts of Brexit on the Japanese Economy [in] Brexit and the Consequences for International Competitiveness, ed. A.M. Kowalski, New York 2018.

European Commission, Employment and decent work, https://ec.europa.eu/international-partnerships/topics/employment-and-decent-work_en (accessed: 5.07.2021).

Folke C., Resilience: The emergence of a perspective for social-ecological systems analyses, "Global Environmental Change" 2006, vol. 16.

Folke C., Biggs R., Norström A.V., Reyers B., Rockström J., Social-ecological resilience and biosphere-based sustainability science, "Ecology and Society" 2016, vol. 21, issue 3.

Folke C., Carpenter S.R., Walker B., Scheffer M., Chapin T., Rockström J., Resilience thinking: integrating resilience, adaptability and transformability, "Ecology and Society" 2010, vol. 15, no. 4.

Global Gender Gap Report 2021, Insight Report, March 2021, http://www3.weforum.org/docs/ WEF_GGGR_2021.pdf (accessed: 12.07.2021).

Hirano M., Japan's GDP likely plunged 26\% in April-June quarter, Nikkei Asia, 1 August 2020, https:// asia.nikkei.com/Economy/Japan-s-GDP-likely-plunged-26-in-April-June-quarter (accessed 5.07.2021).

Hite R.E., Hawes J.M., Understanding The Japanese Culture For Business Success, "Journal of Managerial Issues" 1991, vol. 3, no. 1.

ILO, Decent work and the 2030 Agenda for sustainable development, https://www.ilo.org/global/topics/ sdg-2030/lang--en/index.htm 24.04.2021 (accessed: 24.04.2021).

Imahashi R., Pandemic widens gender gap across Asia. India and Indonesia tumble in WEF ranking; Japan and South Korea inch up, Nikkei Asia, 31 March 2021, https://asia.nikkei.com/Spotlight/Society/Pandemic-widens-gender-gap-across-Asia (accessed: 12.07.2021).

Industry Revitalization Plan, Prime Minister of Japan and His Cabinet, http://www.kantei.go.jp/jp/ singi/keizaisaisei/pdf/en_sesakurei.pdf (accessed: 12.07.2021).

Ishino I., The Oyabun-Kobun: A Japanese Ritual Kinship Institution, "American Anthropologist" 1953, vol. 55 , issue 5 .

Jacoby S., The Origins of Internal Labor Markets in Japan, "Industrial Relations: A Journal of Economy and Society" 1979, vol. 18, issue 2.

Japan Revitalization Strategy - Japan is Back, Prime Minister of Japan and His Cabinet, 14 June 2013, https://www.kantei.go.jp/jp/singi/keizaisaisei/pdf/en_saikou_jpn_hon.pdf (accessed: 12.07.2021). 
Kihara L., Japan eyes another big stimulus package before possible Sept poll - Nikkei, Reuters, 10 June 2021, https://www.reuters.com/world/asia-pacific/japans-suga-compile-big-stimulus-packagearound-summer-nikkei-2021-06-09/ (accessed: 8.07.2021).

Kinebuchi T., 日本的雇用制度再考「タテ社会」の力学基礎に Revisit to the Japanese Style of Employment System: Based on the Dynamics Stemming from the "Vertically-Structured Society"], "Josai Junior College Bulletin" 2015, vol. 32(1).

Kovacic K., The Making of National Robot History in Japan: Monozukuri, Enculturation and Cultural Lineage of Robots, The Nissan Institute of Japanese Studies, School of Interdisciplinary Area Studies, University of Oxford, UK 2018.

Martin J.P., Activation and Active Labour Market Policies in OECD Countries: Stylized Facts and Evidence on their Effectiveness, "IZA Policy Paper" 2014, no. 84.

Mizuno Y., ジョブ型を甘くみるな. 人事・組織、根本から見直しを [Do not underestimate jobu-gata. Towards radical revision of personnel and organization], Nihon Keizai Shimbun (Nikkei), 20 January 2021, https://www.nikkei.com/article/DGXZQODK184VY0Y 1A110C2000000/ (accessed: 24.04.2021).

Moriguchi Ch., Ono H., Institutional Change in Japan. Japanese Lifetime Employment: A Century's Perspective, Working Paper 2004, Stockholm.

Nihon Keizai Shimbun (Nikkei), 年功・順送り人事では変化に後れを取る[The system falls behind the change because of seniority based wages and postponed promotion], 16 June 2020, https://www.nikkei.com/article/DGKKZO60365470V10C20A6EA1000/ (accessed: 24.04.2021).

North D.C., Institutions, Institutional Change and Economic Performance, Cambridge 1990.

OECD, Hours worked, https://data.oecd.org/emp/hours-worked.htm (accessed: 12.07.2021).

OECD, Long-term unemployment rate, https://data.oecd.org/unemp/long-term-unemployment-rate.htm (accessed: 5.07.2021).

OECD, Youth unemployment rate, https://data.oecd.org/unemp/youth-unemployment-rate. htm (accessed: 5.07.2021).

OECD.Stat, Public expenditure and participant stock on LMP, https://stats.oecd.org/Index.aspx?DataSetCode=LMPEXP (accessed: 12.07.2021).

OECD.Stats, Employment/population ratio, https://stats.oecd.org/index.aspx?queryid $=54742$ (accessed: 9.07.2021).

OECD.Stats, Employment: Share of employed in part-time employment, https://stats.oecd.org/ index.aspx?queryid=54746 (accessed: 9.07.2021).

Okutsu A., Sugiura E., Five things to know about Japan's work reform law, Nikkei Asia, 29 June 2018, https://asia.nikkei.com/Economy/Five-things-to-know-about-Japan-s-work-reform-law (accessed: 12.07.2021).

Ono H., Japanese Labor Market Reform. Why is It So Difficult?, Working Paper April 2002, no. 146, Stockholm School of Economics.

Packalen E., Working life in Japan, Eurofound, 6 March 2019, https://www.eurofound.europa.eu/ country/japan\#actors-and-institutions (accessed: 10.05.2021).

Pisano U., Resilience and Sustainable Development: Theory of resilience, systems thinking and adaptive governance, ESDN Quarterly Report 2012, no. 26.

Schaede U., What happened to the Japanese Model? "Review of International Economics" 2004, vol. 12, no. 2.

Shibata S., Gig Work and the Discourse of Autonomy: Fictitious Freedom in Japan's Digital Economy, "New Political Economy" 2020, vol. 25, issue 4.

Soini K., Dessein J., Culture-Sustainability Relation: Towards a Conceptual Framework, "Sustainability" 2016, vol. 8(167) 
Song J., Economic Distress, Labor Market Reforms, and Dualism in Japan and Korea, "Governance-An International Journal of Policy. Administration and Institutions”, July 2012, vol. 25, no. 3.

Song J., Inequality in the Workplace: Labor Market Reform in Japan and Korea, Cornell University Press 2014.

Urban M.C., Johal S., Understanding the Future of Skills, Trends and Global Policy Responses, Skills Next 2020, https://fsc-ccf.ca/wp-content/uploads/2020/01/UnderstandingTheFutureOfSkills-PPF-JAN2020-EN.pdf (accessed: 12.07.2021).

Walker B.H., Resilience: what it is and is not, "Ecology and Society" 2020, vol. 25, no. 2.

Walker B., Holling C.S., Carpenter S.R., Kinzig A., Resilience, Adaptability and Transformability in Social-ecological Systems, "Ecology and Society" 2004, vol. 9, issue 2.

Walker B., Salt D., Reid W., Resilience Thinking. Sustaining Ecosystems and People in Changing World, Washington - Covelo - London 2006.

Watanabe H.R., Institutional Change Under Neoliberal Pressure: Japanese Regulatory Reforms in Labor and Financial Markets, “Asian Politics \& Policy” 2015, vol. 7, no. 3.

World Bank Share of youth not in education, employment or training, total ( $\%$ of youth population) - Japan, https://data.worldbank.org/indicator/SL.UEM.NEET.ZS?locations=JP (accessed: 5.07.2021).

World Bank, Employment to population ratio, https://data.worldbank.org/indicator/SL.EMP. TOTL.SP.ZS?locations=JP (accessed: 9.07.2021).

World Bank, Labor force participation rate, https://data.worldbank.org/indicator/SL.TLF. ACTI.ZS?locations=JP (accessed: 5.07.2021).

World Bank, Part time employment, https://data.worldbank.org/indicator/SL.TLF.PART.ZS?locations $=J P$ (accessed: 9.07.2021).

Yamamoto I., The Need for Work Style Reform in Japan \& Its Impact, Special Article 1, "Japan SPOTLIGHT", May-June 2017.

Yoshino K., Cultural Nationalism in Contemporary Japan: A sociological enquiry, London - New York 1992.

\section{STRESZCZENIE}

\section{DUALIZM RYNKU PRACY W JAPONII W PERSPEKTYWIE RESILIENCE}

W ciągu ostatniej dekady pogłębiała się dychotomia japońskiego rynku pracy między „odporną" formą zatrudnienia regularnego a wysoce elastyczna, ale wrażliwą formą zatrudnienia nieregularnego. Zjawisko to, w połączeniu z wciąż aktualnymi doświadczeniami kryzysu związanego z pandemią COVID-19 oraz nieustannie dokonująca się zmianą otoczenia powodowana rosnącym postępem technologicznym, nasuwa pytanie o trwałość tradycyjnych japońskich praktyk zatrudnienia na całe życie. W artykule poddano analizie środowisko pracy w Japonii za pomocą modelu „odporności” rynku pracy, rozszerzonego o czynnik kulturowy, który pozwala na pełniejsze zrozumienie japońskiego systemu zatrudnienia. Zdaniem autorki ostatnie koncepcje co do zmiany organizacji zatrudnienia w Japonii oraz coraz głośniej i częściej podnoszona konieczność tych zmian mogą przyczynić się do długo oczekiwanej transformacji. 